\title{
Phytoplankton biomass and production in the southeastern Beaufort Sea in autumn 2002 and 2003
}

\author{
Sonia Brugel ${ }^{1, *}$, Christian Nozais ${ }^{2}$, Michel Poulin ${ }^{3}$, Jean-Éric Tremblay ${ }^{4}$, \\ Lisa A. Miller ${ }^{5}$, Kyle G. Simpson ${ }^{6}$, Yves Gratton ${ }^{7}$, Serge Demers ${ }^{1}$ \\ ${ }^{1}$ Institut des sciences de la mer de Rimouski (ISMER), Université du Québec à Rimouski, 310 allée des ursulines, Rimouski, \\ Québec G5L 3A1, Canada \\ ${ }^{2}$ Département de biologie et centre d'études nordiques, Université du Québec à Rimouski, 300 allée des ursulines, Rimouski, \\ Québec G5L 3A1, Canada \\ ${ }^{3}$ Research Division, Canadian Museum of Nature, PO Box 3443, Station D, Ottawa, Ontario K1P 6P4, Canada \\ ${ }^{4}$ Département de Biologie, Université Laval, Pavillon Alexandre-Vachon, Québec City, Québec G1K 7P4, Canada \\ ${ }^{5}$ Centre for Ocean Climate Chemistry, Institute of Ocean Sciences, Fisheries and Oceans Canada, PO Box 6000, \\ 9860 West Saanich Road, Sidney, British Columbia V8L 4B2, Canada \\ ${ }^{6}$ Department of Biology, McGill University, 1205 avenue Dr Penfield, Montréal, Québec H3A 1B1, Canada \\ ${ }^{7}$ Institut national de la recherche scientifique - Eau, Terre et Environnement, 490 de la Couronne, Québec City, \\ Québec G1K 9A9, Canada
}

\begin{abstract}
The phytoplankton community of the Mackenzie shelf and the Amundsen Gulf (southeastern Beaufort Sea) was characterized (e.g. chlorophyll a biomass, primary production and taxonomy) during autumn 2002 (23 September to 14 October) and 2003 (30 September to 14 November). Spatial differences were evident, particularly in early autumn. Total phytoplankton biomass and the contribution of large cells $(>5 \mu \mathrm{m})$ to biomass were higher in the Amundsen Gulf than on the Mackenzie shelf. The community of autotrophic cells $(>10 \mu \mathrm{m})$ was numerically dominated by diatoms in the Amundsen Gulf and by dinoflagellates on the Mackenzie shelf. The abundance of chlorophytes revealed the influence of the Mackenzie River on the Mackenzie shelf. Contrary to 2002, when all measurements were from early October, the phytoplankton community of the Amundsen Gulf in 2003 presented the characteristics of a late bloom, which presumably peaked in late September. In early autumn, however, primary production rates were similar for both years, averaging $75 \mathrm{mg} \mathrm{C} \mathrm{m}^{-2} \mathrm{~d}^{-1}$. High primary production-to-biomass ratios and overall dominance of small cells $(<5 \mu \mathrm{m})$ suggest that pelagic production in the southeastern Beaufort Sea was sustained by active recycling. During autumn 2003, a temporal decrease in phytoplankton biomass and primary production likely resulted from decreasing light availability. Overall, the autumnal primary production estimated in this study, from mid-September to the end of October, could increase the annual primary production previously estimated for the Beaufort Sea by $15 \%$.
\end{abstract}

KEY WORDS: Phytoplankton · Size-fraction · Primary production · Arctic Ocean · Beaufort Sea · Amundsen Gulf · Mackenzie shelf

\section{INTRODUCTION}

The increasing impacts of climate change at northern latitudes make arctic ecosystems a major environmental concern (ACIA 2005). Field studies, as well as numerical simulations, indicate that the Arctic Ocean and more particularly its marginal seas are warming faster than other oceans (Comiso 2003). The arctic seaice minimum extent (i.e. summer) decreased by about $8 \times 10^{5} \mathrm{~km}^{2}$ over the 1978 to 2003 period (Johannessen 
et al. 2004), and numerical models predict that the Arctic Ocean could be free of ice in summer by the end of the 21st century (Serreze et al. 2007) or as early as 2040 (Holland et al. 2006). Since 2002, the Arctic Ocean has experienced record low sea-ice extents, with a new maximum in summer open water in September 2007 (Comiso et al. 2008), suggesting an accelerating loss of sea-ice cover. The Arctic Ocean is also strongly influenced by large river inflow (Macdonald et al. 2004), and the freshwater inputs will likely increase through the intensification of the hydrological cycle (Peterson et al. 2002); therefore, the Arctic Ocean's marginal seas would be even more sensitive to climate change impact (ACIA 2005). Arctic ecosystems are expected to be affected by climate changes, e.g. shifts in the biodiversity and the food web structure (Gradinger \& Bluhm 2005), though it is unclear how these changes will impact the components and pathways of carbon cycling (Wassmann 2004). Analysis of climate-related changes in arctic ecosystems and model validation need to be based on historical measurements in order to identify where the impacts of climate change are most likely to be observed. However, such data are still missing in some biologically active regions and seasons in the Arctic Ocean (Carmack \& Wassmann 2006).

Arctic marine environments are characterized by large seasonal variations in solar radiation and sea-ice cover (Sakshaug \& Slagstad 1991). Indeed, pelagic phytoplankton production is usually constrained to the summer months between sea-ice melt in spring and the freeze-up in autumn, and high phytoplankton production and standing stocks are restricted to relatively short periods within the ice-free season (Sakshaug 2004). Moreover, phytoplankton is the most important mediator of carbon flow in pelagic ecosystems, and phytoplankton cell size is a critical factor in the fate of carbon through the food web (Legendre \& Le Fèvre 1995). For example, carbon export and transfer to higher trophic levels are favoured by large cell production (Legendre \& Le Fèvre 1995). However, blooms of large microphytoplankton cells are often constrained to a couple of weeks and smaller cells, i.e. nano- and picophytoplankton, often dominate outside these periods (Not et al. 2005).

The highest rates of primary production in the Arctic Ocean are observed on continental shelves and in polynyas (Sakshaug 2004). Nevertheless, little research has been undertaken on the phytoplankton dynamics of interior continental shelves due to logistical constraints, and this holds particularly true for the southeastern Beaufort Sea (Carmack et al. 2004). In the Beaufort Sea, the last study of phytoplankton on the Mackenzie shelf was conducted in the late 1980s (Carmack et al. 2004), and very few direct measurements were taken in the Amundsen Gulf (Lee \& Whitledge 2005). Recent satellite-based surveys have revealed a strong interannual variability of the sea-ice cover and potentially of phytoplankton dynamics in the Amundsen Gulf, which contains a large recurrent polynya (Arrigo \& van Dijken 2004). In the current climate change context, the ice-free season (i.e. the phytoplankton productive season), is expected to lengthen (Sakshaug 2004). However, little is known about phytoplankton dynamics at the end of the growth season (Heimdal 1983, Hegseth 1997), under decreasing temperature, sea-ice formation and reduced light availability. Conditions at the end of the productive season have been rarely studied in the Arctic (Hegseth 1997), but numerical models predict that light limitation would terminate phytoplankton growth (Slagstad \& Støle-Hansen 1991).

The spatio-temporal distribution of phytoplankton needs to be studied in order to understand ecosystems and biogeochemical cycles and to later model the impacts of climate change on the Arctic Ocean and its marginal seas (Carmack \& Wassmann 2006). In the framework of the Canadian Arctic Shelf Exchange Study (CASES), the southeastern Beaufort Seacomprising the Mackenzie continental shelf and the Amundsen Gulf - was studied in autumn 2002 (23 September to 14 October) and 2003 (30 September to 14 November). This study focuses on the factors influencing phytoplankton production, biomass distribution (including interannual variations), and dynamics at the end of the growth season in the southeastern Beaufort Sea.

\section{MATERIALS AND METHODS}

Study area. The Mackenzie shelf is shallow and bounded by the Amundsen Gulf to the east, and the Canada Basin to the north (Fig. 1). The surface circulation in the Mackenzie shelf and its surrounding regions is mainly driven by wind forcing, the Mackenzie River discharge, and thermohaline convection during freeze-up (Carmack et al. 2004). The Mackenzie shelf is strongly influenced by the Mackenzie River, which has the highest sediment and organic carbon loads of all arctic rivers (Holmes et al. 2002). Over the sampling area, the water column is typically formed by the polar mixed layer ( $\mathrm{PML}, 0$ to $50 \mathrm{~m}$ ), overlying the cold halocline layer (50 to $200 \mathrm{~m}$ ), mainly formed by waters of Pacific origin, and the Atlantic layer (>200 m) (McLaughlin et al. 1996). Beyond the shelf-break, the surface circulation is dominated by the south branch of the anticyclonic Beaufort gyre that drives the pack ice and the surface waters westward (Carmack \& Macdonald 2002). Below 50 to $85 \mathrm{~m}$, the eastward Beaufort counter-current carries waters of Pacific origin along the slope (Pickart 2004). 


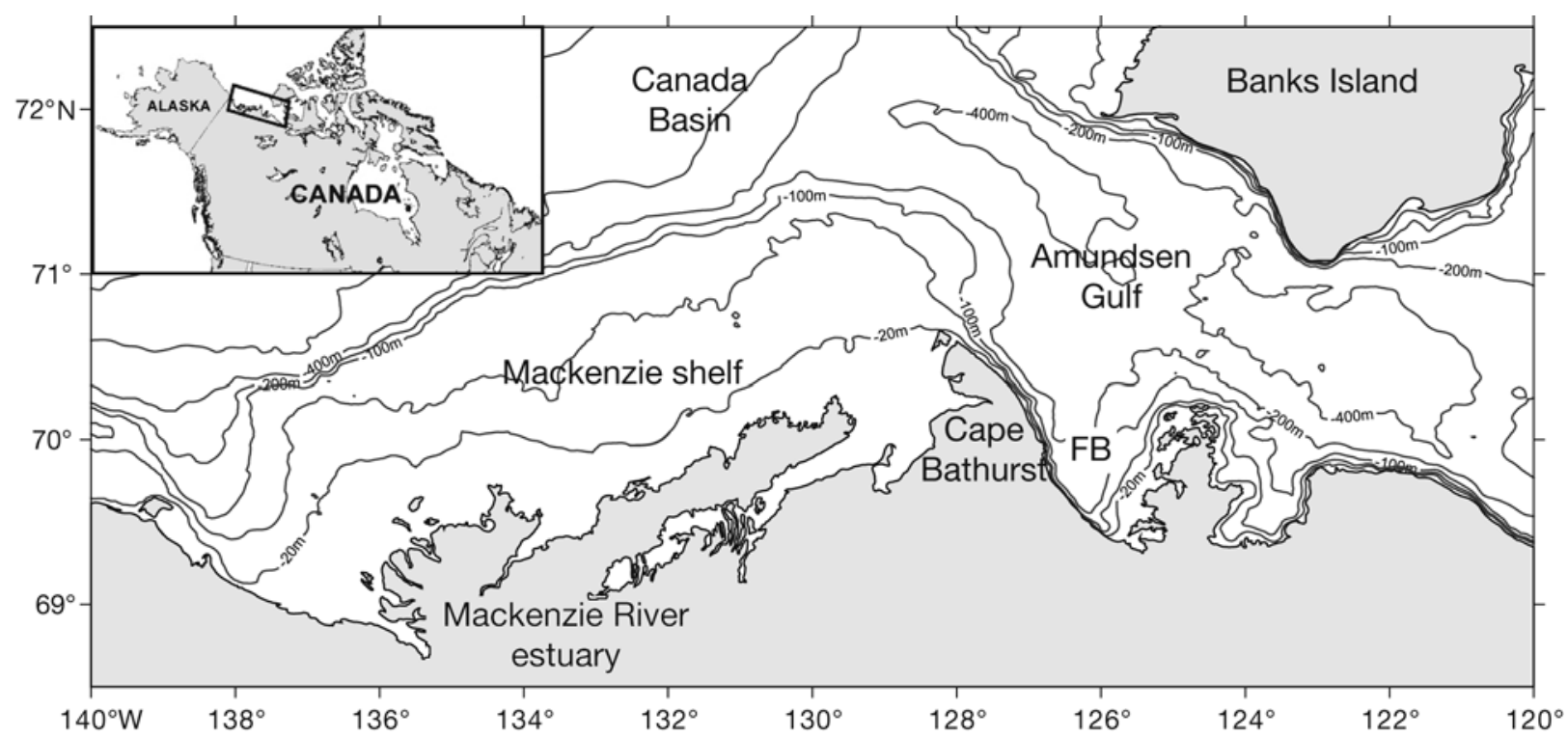

Fig. 1. Location of the study area in the southeastern Beaufort Sea. FB: Franklin Bay

The area is characterized by 3 main features related to sea-ice dynamics: on the shelf, the new sea ice typically forms in October; offshore, the permanent pack ice comprises annual and multiyear sea ice and drifts following the Beaufort gyre; the Cape Bathurst polynya is generally located at the entrance of the Amundsen Gulf (Barber \& Hanesiak 2004).

Stations. Stations were separated according to their locations relative to $128.35^{\circ} \mathrm{W}$, which corresponds to the tip of Cape Bathurst, as in Simpson et al. (2008). Stations east of $128.35^{\circ} \mathrm{W}$ with a depth $>150 \mathrm{~m}$ were considered to be in the Amundsen Gulf region, and stations west of $128.35^{\circ} \mathrm{W}$ on the Mackenzie shelf and slope were considered as Mackenzie shelf stations (Fig. 2) (Stn CA13 in early autumn 2003 was excluded from the shelf region owing to its proximity to the pack ice).

Sampling. Sampling took place in the southeastern Beaufort Sea (69 to $72^{\circ} \mathrm{N}, 120$ to $140^{\circ} \mathrm{W}$ ) over the Mackenzie shelf area and the Amundsen Gulf during autumn 2002 (23 September to 14 October) on board the CCGS 'Pierre Radisson', and during early (30 September to 13 October) and late (16 October to 14 November) autumn 2003 on board the CCGS 'Amundsen'. We separated the sampling periods in early and late autumn periods, according to the time elapsed between sampling of the shelf and gulf regions (1 wk or more) and also to the larger decrease in light availability from mid-October. Water samples were collected with a rosette sampler SBE-carousel (Seabird) fitted with 24 Niskin bottles (each of 12 l) (Ocean Test Equipment), an SBE-9plus CTD and a Seapoint chlorophyll fluorometer. All water samples were collected at fixed depths (surface, 5, 10, 15, 25 and $50 \mathrm{~m}$ ) and at the fluorescence maximum at all stations $(\mathrm{n}=73)$ (Table 1$)$. At stations with primary production estimations $(\mathrm{n}=16)$ (Table 1$)$, additional water samples were taken at 5 or 6 photic depths (detailed in section 'Phytoplankton production'). The photic depths were established after calculating the light attenuation coefficient, $\mathrm{K}_{\mathrm{d}}$, using a Secchi disk

Table 1. Stations sampled for biomass, primary production and taxonomy during all cruises. The number of stations visited is indicated in parentheses

\begin{tabular}{|lcccc|}
\hline Year/season & Sampling period & Biomass & Production & Taxonomy \\
\hline $\mathbf{2 0 0 2}$ & & & & \\
Early autumn & 23 Sep-14 Oct & All stations (36) & $24,49,65,66,83,101$ & $24,49,65,66,83,101$ \\
$\mathbf{2 0 0 3}$ & & & & \\
Early autumn & 30 Sep-13 Oct & All stations (11) & 718, CA07, CA10, CA15, CA18 & 718, CA07, CA10, CA15, CA18 \\
Late autumn & 16 Oct-14 Nov & All stations (26) & $718,709,506,124,112,200$ & $718,715,712,709,706,703,124$, \\
& & & & $112,100,206,200,400,406$, \\
& & & $409,415,306,300$ \\
\hline
\end{tabular}


(Parsons et al. 1984). Samples for phytoplankton were pre-screened onto a $333 \mu \mathrm{m}$ mesh in order to remove large zooplankton.

The depth of the surface mixed layer (SML) was calculated according to Thomson \& Fine (2003) and the bottom of the PML is defined by the 31.6 isohaline (Carmack et al. 2004).

Inorganic nutrient concentrations (nitrate + nitrite, phosphate and silicic acid) were measured on board using standard colorimetric methods (Grasshoff et al. 1999), as described in Schloss et al. (2008) for 2002 and in Simpson et al. (2008) for 2003.

In 2003, downwelling PAR (photosynthetically available radiation) irradiance was collected using a GUV-510 surface radiometer (Biospherical Instruments) from 30 September to 7 November. Data collection was stopped before the end of the cruise due to adverse weather conditions (snowfall).

Chlorophyll a determination. For the determination of phytoplankton chlorophyll a ( $\mathrm{chl}$ a) concentration, water sub-samples of 0.5 to 11 were filtered onto glass fibre filters (poresize $0.7 \mu \mathrm{m}$, Whatman GF/F) (total biomass) and $5 \mu \mathrm{m}$ polycarbonate membrane filters (Poretics) (large cells biomass). Chl a concentrations were determined with a 10-AU Turner Designs fluorometer following $24 \mathrm{~h}$ extraction in $90 \%$ acetone at $5^{\circ} \mathrm{C}$ in the dark without grinding (Parsons et al. 1984). Concentrations of chl a were corrected for phaeopigments by acidification of the extract (Knap et al. 1996). All values were integrated over $50 \mathrm{~m}$ at all stations. At stations with primary production estimates, chl a concentrations were also integrated over the euphotic zone. As the euphotic zone was not measured at all stations, the depth of $50 \mathrm{~m}$ was chosen for the integration of chl a concentration values in order to include the euphotic zone, the PML and the deep chl a maximum for most of the stations.

Phytoplankton production. Particulate primary production was estimated from 6 photic depths in 2002 $(100,40,20,10,5$ and $1 \%$ of surface irradiance) and 5 photic depths in $2003(100,50,25,10$ and $1 \%$ of surface irradiance) using the ${ }^{14} \mathrm{C}$ uptake method (Knap et al. 1996). Samples were incubated in $500 \mathrm{ml}$ polycarbonate bottles (2 light and 1 dark with DCMU [3- $(3,4-$ dichlorophenyl)-1,1-dimethyl urea]), inoculated with 20 to $30 \mu \mathrm{Ci}$ of $\mathrm{NaH}^{14} \mathrm{CO}_{3}$, and placed under in situ simulated conditions in on-deck incubators with running surface seawater and incident irradiances adjusted with neutral density filters. The total added activity was determined in triplicate by adding $250 \mu \mathrm{l}$ of ethanolamine and $10 \mathrm{ml}$ Ecolume scintillation fluid (ICN) to a $250 \mu \mathrm{l}$ inoculated water sub-sample. After $24 \mathrm{~h}$ of incubation, water sub-samples ( $150 \mathrm{ml}$ or more) were filtered onto glass fibre filters (poresize $0.7 \mu \mathrm{m}$, Whatman GF/F) (total particulate primary production) and $5 \mu \mathrm{m}$ polycarbonate membrane filters (Poretics) (large cell particulate primary production). Nonincorporated ${ }^{14} \mathrm{C}$ was removed by addition of $250 \mu \mathrm{l}$ of $0.5 \mathrm{~N} \mathrm{HCl}$. Upon complete evaporation of the acid, $10 \mathrm{ml}$ of Ecolume scintillation cocktail were added. The activity was determined using a Beckman Liquid scintillation system 3801 Series in 2002 and a Packard Liquid Scintillation Analyzer Tri-Carb 2900 TR in 2003. Primary production rates were estimated with the actual dissolved inorganic carbon concentrations measured by coulometric titration (Johnson et al. 1993, DOE 1994). All counts were dark-corrected and daily primary production rates were integrated over the euphotic zone. Incubations were initiated early in the morning (minimal incident PAR) in order to reduce the variability in ${ }^{14} \mathrm{C}$ accumulation (Mingelbier et al. 1994). Water samples for primary production measurements were taken in ice-free waters in early autumn 2002 and 2003, and at stations with no or undefined sea-ice cover (i.e. partial presence of new ice) in late autumn; therefore, no correction for sea-ice concentration was applied.

The $f$-ratio can be estimated from primary production rates following the equation: $f$-ratio $=0.04+$ $0.74\left(P_{\mathrm{L}} / P_{\mathrm{T}}\right)$, where $P_{\mathrm{T}}$ is total particulate primary production in the euphotic zone and $P_{\mathrm{L}}$ is large cells production in the euphotic zone (Tremblay et al. 1997). The phytoplankton new production, which corresponds to the maximum potential export of particulate primary production from the euphotic zone $P_{\mathrm{ex}}$ can be further derived from the $f$-ratios according to the equation: $P_{\mathrm{ex}}=P_{\mathrm{T}} \times f$-ratio.

Taxonomic identification. Water sub-samples $(250 \mathrm{ml})$ were collected at the fluorescence maximum for phytoplankton cell identification and enumeration (Table 1). The samples were fixed with acidic Lugol solution ( $0.4 \%$ final concentration) and stored in the dark at $4^{\circ} \mathrm{C}$ until analysis. Water samples of 50 to $100 \mathrm{ml}$ were settled in Zeiss-type settling chambers for at least $12 \mathrm{~h}$ before cell enumeration with a Leitz Diavert inverted microscope with phase contrast optics at $250 \times$ and $400 \times$. The main taxonomic references used to identify phytoplankton were Tomas (1997), Jensen \& Moestrup (1998), Bérard-Therriault et al. (1999) and Throndsen et al. (2003). Phytoplankton cells unidentified to species or genus level were classified according to algal group and size class: $5-10,11-20,21-50$ and $>50 \mu \mathrm{m}$ for dinoflagellates and diatoms, and $<5,5-10$, 11-20 and $>20 \mu \mathrm{m}$ for chlorophytes, chrysophytes, dictyochophytes, cryptophytes, euglenophytes, prasinophytes, prymnesiophytes and unidentified flagellates.

Statistical analyses. In order to investigate differences in chl a biomass integrated over $50 \mathrm{~m}$ (total and large size fractions) between the different regions and cruises, the non-parametric pair comparison Mann- 
Whitney $U$-test was applied, as the data did not meet normal distribution and homoscedasticity (Zar 1999). The small number of observations for primary production rates and $f$-ratios precluded statistical analyses of regional differences. Association between paired variables of surface values was measured with the Pearson moment product correlation (r coefficient) for all variables, as there were no large deviations from normality (Zar 1999). We ran partial correlations to examine the interactions between 3 variables in order to remove spurious correlations. First-order partial correlation considers the relation between 2 variables, while holding constant the value of a third variable (Zar 1999) (coefficient $r_{X, Y / Z}$ represents the relationship between the variables $x$ and $y$, while holding the variable $z$ constant); significance tests for the first-order partial coefficients were made with Student's $t$-test, with $\mathrm{df}=\mathrm{n}-3$ (Myers \& Well 2003). Regressions were performed on paired variables for which a significant correlation was found. All statistical tests were carried out with the Statistica 6.0 program (StatSoft).

Multivariate approaches were applied to the community analysis. Phytoplankton cell abundance data were ordinated by non-metric multi-dimensional scaling (MDS) (Clarke 1993). The input was a similarity matrix based on Bray-Curtis similarity of 4th roottransformed cell abundances to put more weight on the species composition in the samples (Field et al. 1982). The relevant species supporting regional or temporal differences were further determined by the SIMPER procedure. The multivariate analyses were performed with the program Primer version 5.0 (Plymouth Marine Laboratory).

\section{RESULTS}

\section{Physico-chemical conditions}

Information on the sea-ice cover during the sampling periods was provided from the Canadian Ice Service (http://iceglaces.ec.gc.ca/). In 2002, Stns 18 to 33 and 49 to 65 were sampled in ice-free waters, whereas Stns 36 to 45 were sampled at the edge of the arctic pack ice (Fig. 2a). Newly formed sea ice was present at Stns 69 to 81, while at Stns 83 to 92 the pack ice had moved south so that both old and grey drifting ice were present. Stations in the middle part of the Amundsen Gulf were free of ice at the time of sampling (Stns 95 to 101), whereas stations sampled in the southern part of the gulf (Stns 3 to 15, 104, 107 and 110) were partly covered by new and grey ice. In early autumn 2003, old ice in strips was present at Stns 718 and CA10 over the Mackenzie shelf (Fig. 2b). Stns CA04, CA07 and CA13 were sampled close to the pack ice. In the
Amundsen Gulf, all stations were ice-free the second week of October 2003. In late autumn 2003, newly formed sea ice was present over the Mackenzie shelf and the Amundsen Gulf, and started to consolidate at the beginning of November (Fig. 2c).

The daylength decreased in 2002 from $14 \mathrm{~h}$ on 23 September to $9 \mathrm{~h}$ on 14 October. In 2003 the daylength decreased from 13 to $9 \mathrm{~h}$ for the early autumn period and from $8 \mathrm{~h}$ on 19 October to $3 \mathrm{~h}$ on 19 November for the late autumn period. Daily solar incoming PAR irradiance measured in 2003 declined with time and ranged between 2321 and $7361 \mathrm{mmol}$ photon $\mathrm{m}^{-2}$ $\mathrm{d}^{-1}$ in early autumn and between 336 and $1649 \mathrm{mmol}$ photon $\mathrm{m}^{-2} \mathrm{~d}^{-1}$ in late autumn.

Salinity and temperature observations enabled us to identify the stations strongly influenced by the Mackenzie River outflow. The autumn 2002 temperature and salinity fields throughout the sampling area have been described by Garneau et al. (2006). Sea surface temperature was generally below $-0.5^{\circ} \mathrm{C}$ beyond the influence of the river, while river-influenced stations had warmer surface temperature and low salinity (i.e. Stns 59, 62, 66, 69 and 75; Fig. 2a). However, the marine physical characteristics of the most inshore station (Stn 65) were attributed to upwelling of deeper water (Garneau et al. 2006). During early autumn 2003, sea surface temperature was usually below $-0.5^{\circ} \mathrm{C}$, and only Stn 718 (Fig. 2b) was influenced by the river plume. Later in autumn along the transect off the Mackenzie River mouth, the freshwater influence was only detected at Stns 718 and 715 (Fig. 2c). At that time, sea surface temperature was colder and below $-1^{\circ} \mathrm{C}$ at most stations.

In 2002 and 2003, the SML was generally thinner on the Mackenzie shelf, ranging typically from $5 \mathrm{~m}$ close to the river mouth to $12-15 \mathrm{~m}$ offshore. In the Amundsen Gulf, the average SML depth was usually larger than on the shelf ranging from 7 to $20 \mathrm{~m}$. The SML was generally thicker during late autumn than earlier in the year.

In early autumn 2002 and 2003, the depth of the euphotic zone, defined as the $1 \%$ isolume, ranged from $11 \mathrm{~m}$ close to the Mackenzie River mouth to $50 \mathrm{~m}$ offshore and in the Amundsen Gulf. Later in autumn 2003, the euphotic zone was thinner, ranging from 14 to $36 \mathrm{~m}$ over the whole area.

In both 2002 and 2003, the concentrations of phosphate and silicic acid were always in excess compared to dissolved inorganic nitrogen, which was the limiting element (Simpson et al. 2008). In 2002, nitrate + nitrite concentrations were generally depleted throughout the PML with concentrations well below $1 \mu \mathrm{M}$ in the SML and below 3 to $4 \mu \mathrm{M}$ at the bottom of the PML, and averaging $92 \mathrm{mmol} \mathrm{m}^{-2}$ over the surface $50 \mathrm{~m}$. The Amundsen Gulf area had slightly higher nitrate + 

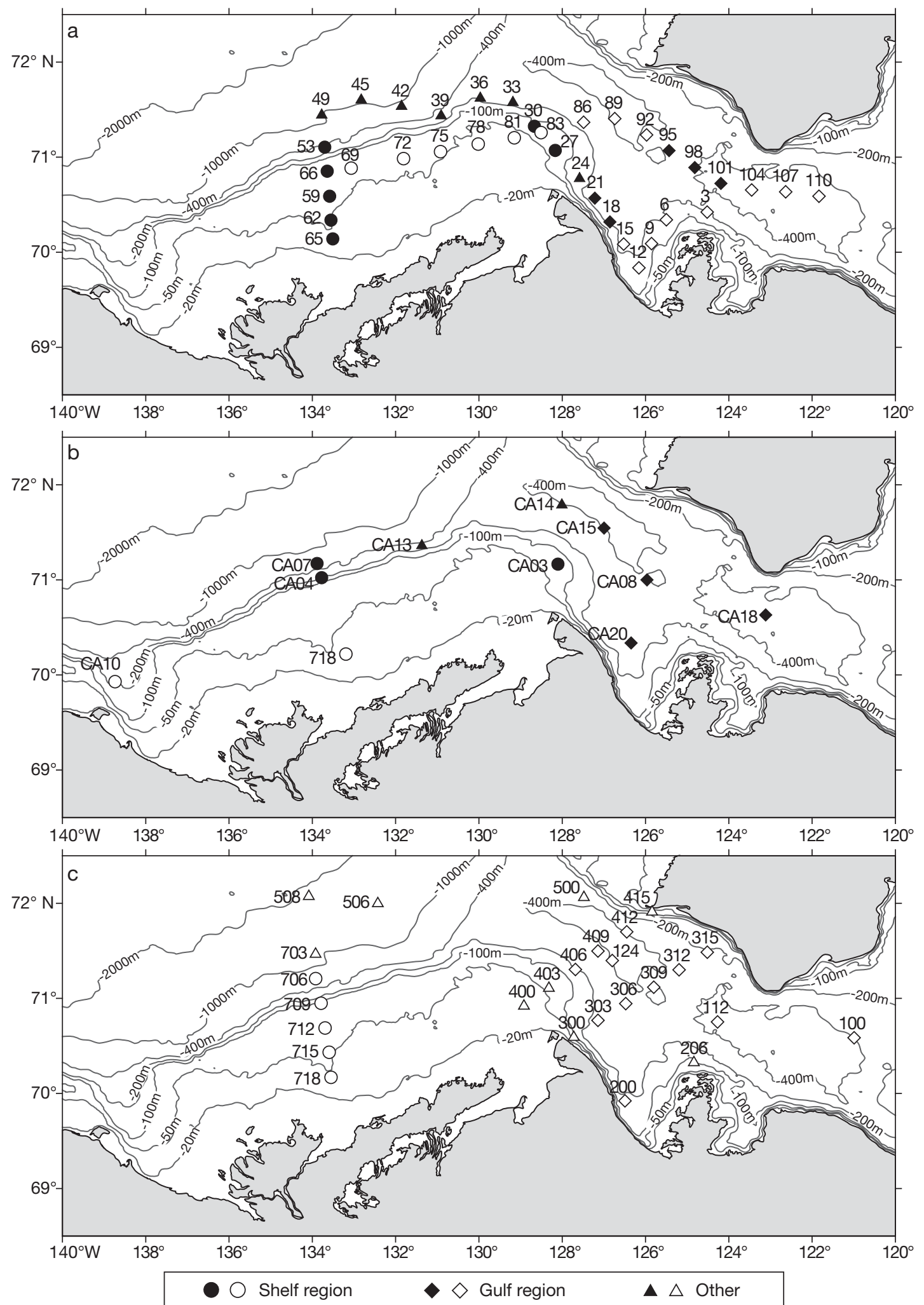

Fig. 2. Location of stations sampled in (a) early autumn 2002, (b) early autumn 2003 and (c) late autumn 2003. Open symbols denote the presence of sea ice at time of sampling, and closed symbols open water conditions 
nitrite concentrations than the shelf area. In early autumn 2003, the nitrate + nitrite distribution was the same with an average availability of $94 \mathrm{mmol} \mathrm{m}^{-2}$ over the first $50 \mathrm{~m}$. Later in autumn, despite a slight replenishment at the bottom of the PML, nitrate + nitrite concentrations remained low in the surface layer and averaged $120 \mathrm{mmol} \mathrm{m}^{-2}$ over the top $50 \mathrm{~m}$.

\section{Chlorophyll a concentrations}

In autumn 2002, chl a concentrations were generally low $\left(<1 \mathrm{mg} \mathrm{m}^{-3}\right)$ throughout the water column. The maximum concentration usually occurred at the surface, except for the stations north of the Mackenzie shelf close to the permanent pack ice (Stns 36 to 45), where a weak deep chlorophyll maximum was observed. The vertical distribution of the chl a concentrations was similar on the Mackenzie shelf and in the Amundsen Gulf: concentrations were maximal in the SML (the top 10 to $20 \mathrm{~m}$ approximately), decreased slightly down to the bottom of the PML or to the sea floor on the shallow shelf and reached very low values


the vertical distribution followed almost the same pattern, but in the middle of the Amundsen Gulf, a deep

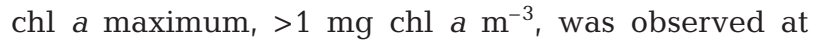
about $25 \mathrm{~m}$, between the SML and the bottom of the PML. Later in the autumn, chl a concentrations decreased with time from 0.80 to $0.15 \mathrm{mg} \mathrm{m}^{-3}$ at the surface. The vertical distribution in the shelf and in the gulf regions followed the same trend as observed in 2002.

Integrated chl a biomass (over $50 \mathrm{~m}$ ), as well as the contribution of large phytoplankton cells to biomass, are presented in Table 2 for both the shelf and gulf regions. In autumn 2002, from the end of September

Table 2. Chl a biomass (integrated over the upper $50 \mathrm{~m}$ ) and relative contribution of large phytoplankton cells $(>5 \mu \mathrm{m})$ to this biomass on the Mackenzie shelf and in the Amundsen Gulf during the different cruises. Mean \pm SD is shown. Number of stations is given in parentheses

\begin{tabular}{|lccc|}
\hline Year/season & Location & $\begin{array}{c}\text { Chl a biomass } \\
\left(\mathrm{mg} \mathrm{m}^{-2}\right)\end{array}$ & $\begin{array}{c}\text { Contribution of } \\
\text { large cells (\%) }\end{array}$ \\
\hline $\mathbf{2 0 0 2}$ & & & \\
Early autumn & Shelf & $11 \pm 4.9(13)$ & $25 \pm 8(13)$ \\
& Gulf & $18 \pm 4.3(16)$ & $31 \pm 11(16)$ \\
$\mathbf{2 0 0 3}$ & & & \\
Early autumn & Shelf & $14 \pm 2.8(5)$ & $26 \pm 12(5)$ \\
& Gulf & $26 \pm 10.5(4)$ & $50 \pm 12(4)$ \\
Late autumn & Shelf & $14 \pm 1.7(5)$ & $34 \pm 10(5)$ \\
& Gulf & $10 \pm 2.9(13)$ & $30 \pm 7(13)$ \\
\hline
\end{tabular}

to mid-October, chl a biomass varied considerably throughout the sampling area, i.e. from 2.8 to $25.9 \mathrm{mg}$ $\mathrm{m}^{-2}$ at Stn 62 in the river plume and Stn 12 in Franklin Bay, respectively (Fig. 3a). Both biomass and contribution of large cells to biomass in the Amundsen Gulf were significantly higher than over the Mackenzie shelf region (Mann-Whitney $U$-test, p < 0.01) (Table 2). Along the pack ice edge (Stns 36 to 45), the biomass and the size structure were highly variable. This high variability was also observed on the Mackenzie shelf, where biomasses were higher at stations strongly influenced by freshwater inputs (i.e. Stns 59, 66, 69 and 75) (Fig. 3a). The biomass was more homogeneously distributed in the Amundsen Gulf, though high biomasses and contributions of large cells to biomass were observed in Franklin Bay. For the same period in 2003, phytoplankton biomass reached comparable values (9.9 to $36.5 \mathrm{mg} \mathrm{chl} \mathrm{a} \mathrm{m}^{-2}$ ) (Fig. 3b). Indeed, on the Mackenzie shelf, there was no difference in biomass and size structure between the 2 years (Mann-Whitney $U$-test, p > 0.05), whereas in the Amundsen Gulf, despite comparable biomasses for both years, the contribution of large cells to biomass was higher in 2003 (Mann-Whitney $U$-test, p < 0.05) (Table 2), reaching a maximum of $61 \%$ of the biomass at Stn CA15. In 2003, the difference between the regions was only evident in the higher contribution of large cells to biomass in the Amundsen Gulf (Mann-Whitney $U$-test, p < 0.05), probably resulting from the small number of observations (Fig. 3b). Later in 2003, from mid-October to midNovember, integrated biomass decreased throughout this period from 15.5 to $6.3 \mathrm{mg} \mathrm{chl} \mathrm{a} \mathrm{m}^{-2}$; this could at least partially explain the differences found between the Mackenzie shelf and the Amundsen Gulf, which was sampled later (Mann-Whitney $U$-test, p $<0.05$ ) (Fig. 3c). However, the biomass size structure was the same for both regions and showed a strong dominance of cells smaller than $5 \mu$ m (Fig. 3c), which contributed on average $70 \%$ of the biomass.

\section{Primary production}

Maximum production rates were generally observed at the surface during both the 2002 and 2003 sampling periods. The contribution of large phytoplankton cells to primary production was the same as that observed for the biomass for all the sampling periods (data not shown). Integrated particulate primary production rates, which were estimated from the end of September to the beginning of November, are presented in Fig. 4. From the end of September to mid-October 2002, integrated primary production rates averaged $73 \pm 36$ (SD, here and elsewhere) $\mathrm{mg} \mathrm{C} \mathrm{m}^{-2} \mathrm{~d}^{-1}$, which was close to the average value of $78 \pm 27 \mathrm{mg} \mathrm{C} \mathrm{m}^{-2} \mathrm{~d}^{-1}$ for the same 

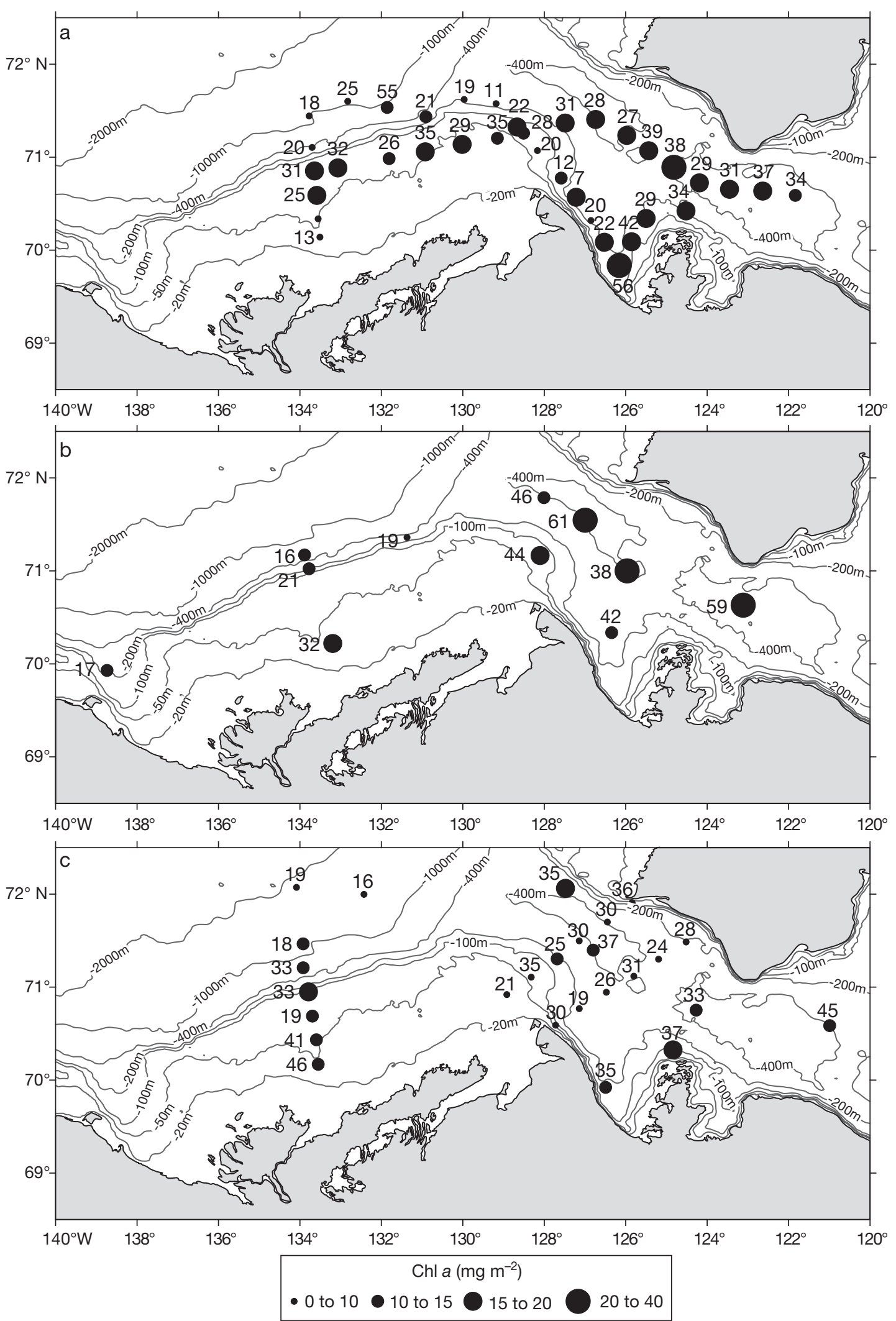

Fig. 3. Spatial distribution of chl a biomass (integrated over $50 \mathrm{~m}$ ) in $\mathrm{mg} \mathrm{chl} \mathrm{a} \mathrm{m}^{-2}$ during (a) early autumn 2002, (b) early autumn 2003 and (c) late autumn 2003. Station values are the percentage contribution of large phytoplankton cells (>5 $\mu \mathrm{m})$ to biomass 




Fig. 4. Rates of total particulate primary production $\left(P_{\mathrm{T}}\right)$ and estimates of maximum potential export of particulate primary production $\left(P_{\mathrm{ex}}\right)$ integrated over the euphotic zone (in $\mathrm{mg} \mathrm{C} \mathrm{m}^{-2} \mathrm{~d}^{-1}$ ) during early autumn 2002 (Stns 24, 49, 65, 66, 83 and 101), early autumn 2003 (Stns 718, CA07, CA10, CA15 and

CA18) and late autumn 2003 (Stns 718, 709, 506, 124, 112 and 200) the primary production in the Amundsen Gulf. Later in the season, $P_{\text {ex }}$ decreased like the primary production rates to low levels of $4 \pm 2 \mathrm{mg} \mathrm{C} \mathrm{m}^{-2} \mathrm{~d}^{-1}$ on average.

\section{Cell abundance and taxonomic composition}

The phytoplankton communities of the Mackenzie shelf and Amundsen Gulf regions were composed of 229 taxa, including 53 diatom, 64 dinoflagellate and 45 flagellate species. In early autumn, phytoplankton cell abundances were comparable for 2002 and 2003, ranging from $14 \times 10^{4}$ to $82 \times$ $10^{4}$ cells $1^{-1}$ and from $17 \times 10^{4}$ to $73 \times 10^{4}$ cells $1^{-1}$, respectively, while decreasing in late period in 2003. Later in 2003, production rates decreased strongly until 4 November and averaged onethird of the rates seen earlier in the season $(23 \pm 11 \mathrm{mg}$ $\left.\mathrm{C} \mathrm{m}^{-2} \mathrm{~d}^{-1}\right)$.

In $2002, f$-ratios were about 0.17 for the whole sampling area. In 2003 for the same period, $f$-ratios were about the same on the Mackenzie shelf area (0.18), whereas higher values above 0.30 were recorded in the Amundsen Gulf. During the second half of October, $f$-ratios remained at about the same level as in 2002 or earlier in the season in 2003 on the Mackenzie shelf and averaged 0.17 .

The potential export of primary production $\left(P_{\mathrm{ex}}\right)$ from the euphotic zone was estimated on the basis of the $f$-ratio calculations. $P_{\text {ex }}$ estimates were variable throughout the sampling area and the seasons (Fig. 4). In 2002, $P_{\text {ex }}$ averaged $14 \pm 10 \mathrm{mg} \mathrm{C} \mathrm{m}^{-2} \mathrm{~d}^{-1}$ and never exceeded $25 \%$ of the primary production. One year later, $P_{\text {ex }}$ rates were almost the same, averaging $25 \pm$ $22 \mathrm{mg} \mathrm{C} \mathrm{m} \mathrm{m}^{-2} \mathrm{~d}^{-1}$, but they accounted for up to $60 \%$ of autumn 2003, with abundances ranging from $15 \times 10^{4}$ to $46 \times 10^{4}$ cells $\mathrm{l}^{-1}$. The phytoplankton community was mainly composed of phytoflagellates, which accounted for 58 to $82 \%$ of the cell abundance during all the sampling periods, except in early autumn 2003 in the Amundsen Gulf, where the community was dominated by diatoms (49\% of the cell abundance on average). During both sampling periods in 2002 and 2003, no cyanobacteria were observed in samples from the Mackenzie shelf and the Amundsen Gulf. Some regional differences based on the main algal classes were observed during all sampling periods (Table 3). Chlorophytes were only present on the Mackenzie shelf and even there at only very low abundances (1106 to 2212 cells $\mathbf{l}^{-1}$ ). In the Amundsen Gulf, dinoflagellates were mostly represented by athecate species from the genera Gymnodinium Stein or Gyrodinium Kofoid et Swezy, whereas in the shelf area thecate species, e.g. Heterocapsa rotundata (Lohmann) Hansen, were more abundant. Finally, the Mackenzie shelf

Table 3. Average percentage contribution of the major algal groups to the phytoplankton cell abundances on the Mackenzie shelf and in the Amundsen Gulf for the 2 sampling years (in early autumn 2002, Stn 65 was not included in the average calculation of the shelf region). Diat: diatoms; Cent: centric diatoms; Penn: pennate diatoms; Din: dinoflagellates; Ath: athecate dinoflagellates; Thec: thecate dinoflagellates; Chlo: chlorophytes; Chrys: chrysophytes; Dict: dictyochophytes; Crypt: cryptophytes;Pras: prasinophytes; Prym: prymnesiophytes; Flag: unidentified flagellates

\begin{tabular}{|c|c|c|c|c|c|c|c|c|c|c|c|c|c|c|}
\hline Year/season & Location & Diat & Cent & Penn & Din & Ath & Thec & Chlo & Chrys & Dict & Cryp & Pras & Prym & Flag \\
\hline \multicolumn{15}{|l|}{2002} \\
\hline \multirow[t]{2}{*}{ Early autumn } & Shelf & 1.1 & 0.7 & 0.4 & 9.7 & 4.7 & 5.0 & 0.3 & 1.4 & 2.1 & 7.2 & 26.2 & 5.9 & 36.4 \\
\hline & Gulf & 6.5 & 4.1 & 2.5 & 11.6 & 9.7 & 1.9 & 0.0 & 0.5 & 2.8 & 5.7 & 4.3 & 21.3 & 40.2 \\
\hline \multicolumn{15}{|l|}{2003} \\
\hline \multirow[t]{2}{*}{ Early autumn } & Shelf & 4.9 & 3.6 & 1.3 & 20.8 & 10.0 & 10.8 & 0.5 & 0.8 & 1.2 & 6.1 & 17.0 & 14.7 & 17.1 \\
\hline & Gulf & 48.7 & 45.0 & 3.7 & 8.9 & 8.0 & 0.9 & 0.0 & 0.6 & 0.4 & 1.5 & 0.5 & 4.9 & 30.3 \\
\hline \multirow[t]{2}{*}{ Late autumn } & Shelf & 3.4 & 2.9 & 0.5 & 14.2 & 8.1 & 6.1 & 0.8 & 0.6 & 2.3 & 2.0 & 15.3 & 25.0 & 25.6 \\
\hline & Gulf & 4.2 & 2.7 & 1.5 & 9.7 & 9.4 & 0.3 & 0.0 & 0.0 & 1.4 & 1.2 & 1.8 & 23.9 & 53.0 \\
\hline
\end{tabular}


area also showed higher abundances of prasinophytes (Pyramimonas spp.) and lower abundances of diatoms than the Amundsen Gulf.

We further examined phytoplankton communities using MDS analysis (Fig. 5). In 2003, samples from the Mackenzie shelf and the Amundsen Gulf were well separated, whereas this regional difference was less pronounced in 2002. Early autumn 2003 samples from the Amundsen Gulf were also distinct from those of the late autumn period. On the Mackenzie shelf, the same species or genera were responsible for the similarity within and between the sampling season, i.e. Chrysochromulina spinifera (Fournier) Pienaar et Norris, Heterocapsa rotundata, Pyramimonas spp., Gymnodinium spp. (11 to $20 \mu \mathrm{m})$ and $<5 \mu \mathrm{m}$ unidentified flagellates. In the shelf region in 2003, the community composition of the 2 sampling periods, i.e. early and late autumn, had a similarity higher than $50 \%$, preventing separation on the MDS plot. The outlier from the 'shelf 2002' group (upper right hand corner of Fig. 5) was Stn 65; there pennate diatoms were unusually abundant $(2 \times$

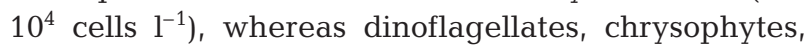
cryptophytes and prasinophytes had very low cell abundances, and chlorophytes and choanoflagellates were completely absent. In the Amundsen Gulf, the dissimilarity between early and late autumn 2003 was mostly due to the following centric diatom taxa which dominated in early autumn: Chaetoceros contortus Schütt, C. socialis Lauder, C. diadema (Ehrenberg) Gran, C. constrictus Gran, C. ingolfianus Ostenfeld, spores of Chaetoceros spp., Leptocylindrus danicus

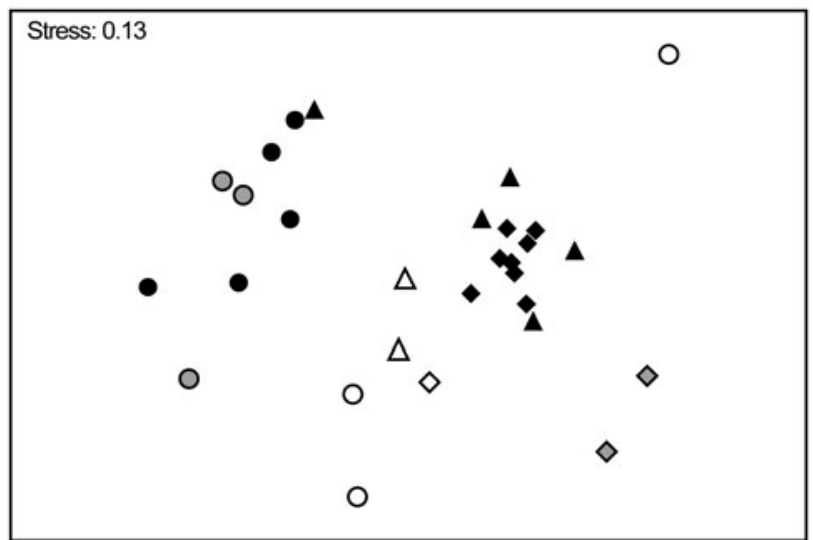

Shelf O Early autumn 2002 O Early autumn 2003 - Late autumn 2003 Gulf $\diamond$ Early autumn $2002 \diamond$ Early autumn 2003 Late autumn 2003 Other $\Delta$ Early autumn 2002 A Late autumn 2003

Fig. 5. Multidimensional scaling ordination plot of phytoplankton community composition (based on taxa abundances) of samples collected in the Mackenzie shelf (shelf, circles) and Amundsen Gulf (gulf, diamonds) regions and at stations outside these regions (other, triangles)
Cleve and Attheya septentrionalis (Østrup) Crawford. On the contrary, in late autumn 2003, the phytoplankton community was characterized by the dominance of $<10 \mu \mathrm{m}$ unidentified flagellates, Chrysochromulina spinifera, Chrysochromulina spp., Gymnodinium spp., Amphidinium cf. kesslitzii Schiller, Pseudopedinella pyriforme Carter and Thalassionema nitzschioides (Grunow) Mereschkowsky.

\section{DISCUSSION}

Estimates of phytoplankton biomass in the Beaufort Sea are very scarce, with none available at all for the end of the productive period (the autumn) until now (Carmack et al. 2004). However, the low biomass $\left(<1 \mathrm{mg} \mathrm{chl} \mathrm{a} \mathrm{m}^{-3}\right.$ ) we observed during 2 consecutive autumn periods are consistent with concentrations measured at the end of September in waters northwest of Spitsbergen (Heimdal 1983). Integrated biomasses for the whole Beaufort Sea were on average 15.8 and $10.5 \mathrm{mg}$ chl a m${ }^{-2}$ for early and late autumn, respectively, consistent with the range of 9.6 to $24.0 \mathrm{mg} \mathrm{chl} a$ $\mathrm{m}^{-2}$ measured in early October in the Barents Sea (Hegseth 1997). Our biomass estimates are also within

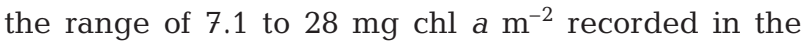
Weddell Sea during austral autumn in April (Dower et al. 1996) but twice as high as the range of 2.4 to $4.1 \mathrm{mg}$

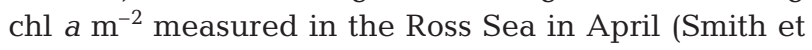
al. 2000). During the 2 autumnal seasons and throughout the study area, except in early autumn 2003 in the Amundsen Gulf, the phytoplankton biomass was generally dominated by small phytoplankton cells $(<5 \mu \mathrm{m})$, which contributed about $70 \%$ of the biomass. The dominance of small cells has been previously reported for the Beaufort Sea in autumn 2002 (Garneau et al. 2006, Schloss et al. 2008) and in the Greenland Sea in October (Gradinger \& Ikävalko 1998), as well as in summer in the central Arctic Ocean (Gosselin et al. 1997) and the Barents Sea (Not et al. 2005).

During the present study, the strong stratification constrained the vertical distribution of the phytoplankton biomass in the shallow SML and the PML. In icecovered regions, concentration of phytoplankton biomass in upper waters is typical, owing to stratification from summer ice melt (Borstadt \& Gower 1984). Consistent with previous studies in the Beaufort Sea (Carmack et al. 2004), nitrogen was the potential limiting element for phytoplankton growth, as indicated by N/P ratios always less than 6 in the upper $50 \mathrm{~m}$. The winds during our sampling periods were only episodic (Environment Canada Weather Archive, www.climate. weatheroffice.ec.gc.ca/) and were unable to significantly break down the stratification and replenish nitrogen in the surface water layers. In autumn 2003, 
Simpson et al. (2008) reported high ammonium concentrations of $17.4 \mathrm{mmol} \mathrm{m} \mathrm{m}^{-2}$ in the PML, which accounted for about $20 \%$ of the total inorganic nitrogen sources. These high ammonium concentrations suggest active nitrogen recycling in the upper water column, supporting the general dominance, in terms of biomass, of small phytoplankton cells observed in 2003 (except in the Amundsen Gulf in early autumn).

\section{Spatial distribution}

Despite different sampling coverage during the 2 years, some regional differences in the phytoplankton community between the Mackenzie shelf and the Amundsen Gulf regions persisted, apart from the early autumn period in the Amundsen Gulf. The spatial differences were based on integrated phytoplankton biomass levels and biomass size structure on the $5 \mu \mathrm{m}$ threshold, and further confirmed by taxonomic identifications. In the early autumn periods of 2002 and 2003, the Amundsen Gulf was characterized by higher biomasses and a higher contribution of large phytoplankton cells to biomass compared to the Mackenzie shelf region (Table 2). The stronger stratification on the Mackenzie shelf, likely due to freshwater inflow, could maintain less favourable conditions for phytoplankton growth, as the Mackenzie River is only a weak source of nitrogen (Carmack et al. 2004, Simpson et al. 2008).

Prasinophytes were an important group of the Mackenzie shelf phytoplankton community, accounting for up to $31 \%$ of the total phytoplankton cell abundance (Table 3 ); this is consistent with pigment analyses performed by Lovejoy et al. (2007), showing that prasinophytes made up $38 \%$ of chl a concentrations in autumn 2002. The taxonomic composition of dinoflagellates was also markedly different between the Mackenzie shelf and the Amundsen Gulf (Table 3), with comparable cell abundances of thecate and athecate species in the shelf region as opposed to much greater cell numbers for athecate species in the gulf region. Thecate dinoflagellates were mainly represented by a single species Heterocapsa rotundata, which is autotrophic (Olli 1999). Athecate dinoflagellates were mostly composed of species from the genera Gymnodinium and Gyrodinium, which are capable of heterotrophy (Levinsen et al. 1999, Jensen \& Hansen 2000). Thecate dinoflagellates dominated the abundance of autotrophic phytoplankton cells larger than $10 \mu \mathrm{m}$ on the Mackenzie shelf, while diatoms were paramount for this group in the Amundsen Gulf for all sampling periods. The high contribution of potentially heterotrophic athecate dinoflagellates to cell abundance, among cells larger than $10 \mu \mathrm{m}$, reinforces the importance of the microbial food web in the southeastern
Beaufort Sea during the autumnal season (Parsons et al. 1989, Garneau et al. 2006, Simpson et al. 2008). Chlorophytes were only observed on the Mackenzie shelf. During late autumn 2003, their abundance decreased with the distance offshore, which implied a dilution of the freshwater species cells as the river waters spread over the shelf; a similar feature was reported for the coastal Laptev Sea (Tuschling et al. 2000).

In 2002, the more intensive sampling over the Mackenzie shelf highlighted the high spatial variability and the importance of the freshwater input over this region. In front of the Mackenzie River estuary, stations close to the river mouth (i.e. Stns 65 and 62) had lower biomasses and contribution of large cells to biomass compared to the group of stations offshore (i.e. Stns 59, 66 and 69) (Fig. 3a). In 2002, the Mackenzie River plume was deflected to the west before curving back to the east further offshore (Garneau et al. 2006), which may explain the higher biomasses recorded at the group of stations with low surface salinities (i.e. Stns 59, 66 and 69). This group of stations was isolated from the river mouth by wind-driven upwelling of higher-salinity deep waters (Garneau et al. 2006), which was observed at Stn 65. At this station, despite low biomass, maximum fluorescence occurred near the bottom at $31 \mathrm{~m}$. The phytoplankton community was characterized by low abundance of flagellate groups and high numbers of pennate diatoms, including numerous empty frustules, and also by low phaeopigment concentrations compared to total chlorophyllous pigments (data not shown). Thus, upwelling likely led to the development of a deep maximum of actively growing phytoplankton cells $20 \mathrm{~m}$ above the bottom (Retamal et al. 2008). Another location of interest is Franklin Bay in the southwest of the Amundsen Gulf region (Fig. 1). There, high phytoplankton biomasses were observed in 2002 (Fig. 3a), with a high contribution of large cells, which probably transfer the food energy required to sustain the high zooplankton biomass (Darnis et al. 2007) and high benthic meiofaunal biomass (Bessière et al. 2007).

During the study period, the phytoplankton biomass and its size structure were more variable over the Mackenzie shelf area. Multiyear ice often drifted over this region in early autumn and the resulting intermittent shading of the water column could have been partly responsible for the variability in phytoplankton standing stock over the Mackenzie shelf region.

\section{Interannual variability}

In the Amundsen Gulf, the phytoplankton community was different between the 2 years, even though it was sampled during the second week of October in 
both cases. In 2002, the phytoplankton community was typical of post-bloom conditions under limited nitrogen availability, with low biomass concentrated in the surface layer and a contribution of large cells around $30 \%$, which seems to be a baseline value for autumn in the Amundsen Gulf (Table 2). In 2003, at stations in the middle of the Amundsen Gulf, phytoplankton biomass was still reaching high values, with a deep chl a maximum; the biomass was dominated by large cells (50\%), and the phytoplankton abundance by centric diatoms. However, the low nitrate concentration and the high abundance of centric diatom spores (up to $13 \%$ of centric diatom cell numbers) at the deep chl a maximum of Stns CA15 and CA18 suggest that the phytoplankton community was at the end of a bloom period in the second week of October 2003. Arrigo \& van Dijken (2004) presented seasonal trends of SeaWiFS-derived chlorophyll concentrations from 1998 to 2002 in the Amundsen Gulf. An autumnal bloom seemed to be a recurrent feature, even though the timing, importance and duration of these blooms varied widely over these 5 years. In 2002, the autumnal bloom started at the end of August and was already over by October, when we sampled the region. The autumnal bloom occurring latest in the season was observed at the end of September 2000 and was of low amplitude. Following the pattern of Arrigo \& van Dijken (2004), the phytoplanktonic community structure we observed during the second week of October 2003 could imply that the bloom had started in the last week of September.

On the Mackenzie shelf, the few stations sampled in early autumn 2003 do not allow us to comment on the interannual variability in that area.

\section{Temporal changes}

In the Beaufort Sea, the temporal evolution during autumn 2003 was characterized by a decrease in biomass and taxonomic diversity from the end of September to mid-November, and this trend was even more pronounced in the Amundsen Gulf, where a bloom ended during the early autumn period. As the season progressed, the light availability and the daylength sharply decreased, surface temperature dropped and new ice formed, which further limited light penetration into the water column. As the Mackenzie River inflow strongly influences the surface temperature over the Mackenzie shelf, the effect of the temperature decrease was examined only for the Amundsen Gulf. Temperature did not directly influence phytoplankton growth, since there was no significant partial correlation between surface chl a concentration and temperature $(T)$ ( $t$-test, $\mathrm{p}>0.05)$. However, surface chl $a$ concentrations were strongly correlated with the day- length $(d)\left(\mathrm{r}_{\mathrm{chl} a, d / T}=0.69\right.$, t-test $\left.\mathrm{p}<0.05\right)$. During autumn 2003, integrated phytoplankton biomass decreased exponentially when daylength was shorter than 8 h (Fig. 6). Light availability was therefore likely the most important factor constraining phytoplankton production in late autumn. At the end of October, strong southeast winds blew in the Amundsen Gulf region (Environment Canada Weather Archive, www. climate.weatheroffice.ec.gc.ca/), and were likely responsible for the slight replenishment of nutrients at the bottom of the PML. However, phytoplankton could not take advantage of the nutrient availability because of low light availability. Even though the influence of sea-ice formation on phytoplankton could not be assessed, owing to the nature of the data available, the ice cover probably shaded the water column; thus, the relationship observed between the daylength and the phytoplankton biomass likely includes the effect of the ice cover. However, in the context of climate change, which would lengthen the ice-free season at high latitude, the phytoplankton production season would probably not be extended in autumn, since light availability (i.e. solar incoming irradiance and daylength) would remain the main factor constraining phytoplankton growth.

\section{Phytoplankton production}

Primary production rates for early autumn on the Mackenzie shelf ranged from 15 to $119 \mathrm{mg} \mathrm{C} \mathrm{m}^{-2} \mathrm{~d}^{-1}$ (Fig. 4), approximating the range (40 to $100 \mathrm{mg} \mathrm{C} \mathrm{m}^{-2}$ $\mathrm{d}^{-1}$ ) reported in August by Carmack et al. (2004), but lower than summer primary production rates (100 to

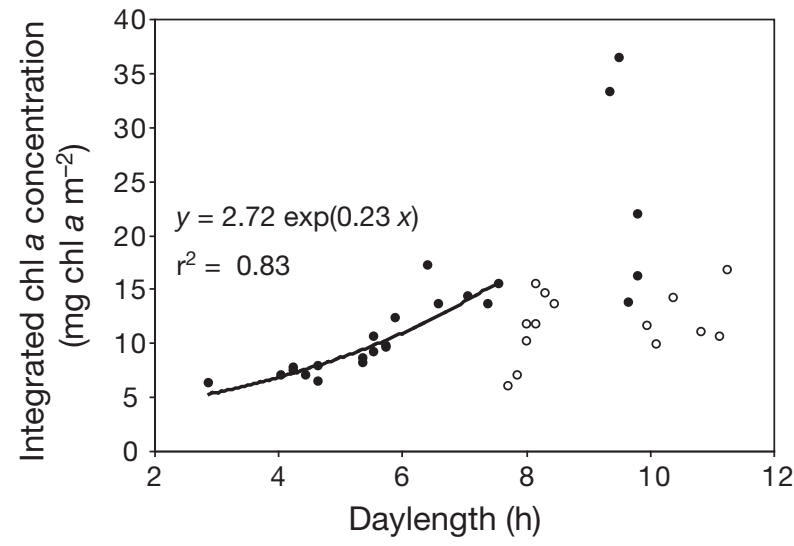

Fig. 6. Relationship between daylength and chl a biomass (integrated over $50 \mathrm{~m}$ ) in early and late autumn 2003. The non-linear regression was only applied to stations sampled in the Amundsen Gulf during late autumn. Closed symbols: stations in the Amundsen Gulf; open symbols: stations out of the Amundsen Gulf, including those from the Mackenzie shelf region 
$1190 \mathrm{mg} \mathrm{C} \mathrm{m} \mathrm{m}^{-2}$ ) measured by Hsiao et al. (1977). The Mackenzie shelf production was also comparable to the 50 to $170 \mathrm{mg} \mathrm{C} \mathrm{m}^{-2} \mathrm{~d}^{-1}$ reported for the Laptev Sea/Lena River system in September (Sorokin \& Sorokin 1996). In early October, primary production ranged from 92 to $105 \mathrm{mg} \mathrm{C} \mathrm{m}^{-2} \mathrm{~d}^{-1}$ in the Amundsen Gulf, while 2 mo before our 2002 sampling (i.e. in August 2002), Lee \& Whitledge (2005) found similar rates ranging from 79 to $145 \mathrm{mg} \mathrm{C} \mathrm{m}^{-2} \mathrm{~d}^{-1}$ in the Amundsen Gulf and Canada Basin. Prior to the present study, estimates of autumnal primary production made at the latest time in the season in the Arctic Ocean were also similar, ranging from 72 to $148 \mathrm{mg} \mathrm{C}$ $\mathrm{m}^{-2} \mathrm{~d}^{-1}$ at the end of September and beginning of October northwest of Spitsbergen (Heimdal 1983). Primary production rates decreased to low levels of 12 to $43 \mathrm{mg} \mathrm{C} \mathrm{m}^{-2} \mathrm{~d}^{-1}$ by the beginning of November, and were close to austral autumnal estimates (April) of 22 to $27 \mathrm{mg} \mathrm{C} \mathrm{m}^{-2} \mathrm{~d}^{-1}$ in the Weddell Sea (Dower et al. 1996) and 13 to $18 \mathrm{mg} \mathrm{C} \mathrm{m} \mathrm{m}^{-1}$ in the Ross Sea (Smith et al. 2000).

The persistent nitrate depletion observed during the present study, together with the high integrated primary production:biomass ratios (usually $>5$ ) in early autumn, suggests that active phytoplankton grazing prevented the accumulation of phytoplankton biomass and also that recycling was efficient. Such highly dynamic food webs have previously been reported in the Arctic Ocean by Wheeler et al. (1996). The $f$-ratios estimated from the size structure of the phytoplankton community were low and close to August $f$-ratios measured in the Canada Basin and the Amundsen Gulf $(0.25 \pm 0.13$, Lee \& Whitledge 2005) and in the Chukchi Sea (0.05 to 0.38, Cota et al. 1996), where phytoplankton production was dependent upon ammonium. Thus, the $f$-ratio estimates further support the high recycling efficiency prevailing in the southeastern Beaufort Sea during autumn.

The potential phytoplankton production that could be exported from the euphotic zone was only about $17 \%$ for the whole study. In the Amundsen Gulf, we estimated a high potential carbon export out of the euphotic zone at $40 \%$ of the primary production in October 2003, probably resulting from the declining bloom situation. However, the export out of the upper halocline would probably be even lower, consistent with a marine particulate organic carbon flux of $22 \%$ of the primary production measured by sediment traps at $200 \mathrm{~m}$ north of Franklin Bay for the same period (Forest et al. 2008).

The new production estimates (from $f$-ratios) derived from the size structure of the phytoplankton community were in good agreement with the new production based on ${ }^{15} \mathrm{~N}$ uptake experiments conducted during the CASES program (Simpson 2008). Moreover, vari- ous estimation methods of potential carbon production export were compared by Garneau et al. (2007) for the North Water polynya, and they concluded that the method of Tremblay et al. (1997) gave good estimates of new production in arctic seas. The results of the present study further support this statement.

In the Arctic, most annual phytoplankton production calculations, based on direct primary production measurements, are estimated over a 120 d or $150 \mathrm{~d}$ period, usually starting in May or June and ending in September. However, blooms can occur even as late as October (Hegseth 1997, Arrigo \& van Dijken 2004), and phytoplankton is still capable of carrying out photosynthesis in November (Richardson et al. 2005). Carmack et al. (2004) estimated an annual production of 12 to $16 \mathrm{~g} \mathrm{C} \mathrm{m}^{-2} \mathrm{yr}^{-1}$ from early April to early September in the Beaufort Sea. Based on our measurements, from mid-September to the end of October, primary production would be around 3.3 and $2.3 \mathrm{~g} \mathrm{C}$ $\mathrm{m}^{-2}$, in the Amundsen Gulf and on the Mackenzie shelf, respectively; thus, the annual primary production estimate of Carmack et al. (2004) would be increased by 14 to $19 \%$. Autumnal primary production is rarely measured, owing to logistical difficulty in accessing arctic regions. However, in the Beaufort Sea, the autumnal production from mid-September to the end of October (roughly $45 \mathrm{~d}$ ) accounted for at least $15 \%$ of the total annual production. Thus, autumnal phytoplankton production can significantly contribute to annual production in arctic systems, at least at latitudes similar to that of the Beaufort Sea (e.g. Chukchi Sea, East Siberian Sea), and the 'productivity period' should be extended by at least 1 mo for such arctic systems.

Acknowledgements. This study was supported by grants from the Natural Sciences and Engineering Research Council (NSERC) of Canada (Research Network grant to S.D., Y.G. and M.P.), by the financial support from the Canadian Museum of Nature to M.P., and from the Fisheries and Oceans Canada Strategic Science Fund to L.A.M. Partial operating funds for the CCGS 'Amundsen' were provided by the International Joint Ventures Fund of the Canada Foundation for Innovation and the Fonds Québécois de la Recherche sur la Nature et les Technologies (FQRNT). S.B. received a post-graduate scholarship from the Institut des sciences de la mer de Rimouski (ISMER). We thank the officers and crew of the CCGS 'Pierre Esprit Radisson' and CCGS 'Amundsen' for their invaluable assistance during the autumn expeditions of 2002 and 2003 in the Beaufort Sea, M. Fortier, D. Barber and L. A. Miller (chief scientists). We are grateful to M. Robert, M.-E. Rail, G. Caron and K. Lacoste for fieldwork, S. Lessard and L. Bérard-Therriault for taxonomic identification, P. Guillot for CTD data processing and N. M. Price for nutrients data. We acknowledge the 2 anonymous reviewers for their useful comments. This is a contribution to the research program of the Canadian Arctic Shelf Exchange Study (CASES), ISMER and Québec-Océan. 


\section{LITERATURE CITED}

ACIA (2005) Arctic climate impact assessment. Cambridge University Press, New York

Arrigo KR, van Dijken GL (2004) Annual cycles of sea ice and phytoplankton in Cape Bathurst polynya, southeastern Beaufort Sea, Canadian Arctic. Geophys Res Lett 31, L08304, doi:10.1029/2003GL018978

Barber DG, Hanesiak JM (2004) Meteorological forcing of sea ice concentrations in the southern Beaufort Sea over the period 1979 to 2000. J Geophys Res 109, C06014, doi:10. 1029/2003JC002027

Bérard-Therriault L, Poulin M, Bossé L (1999) Guide d'identification du phytoplancton marin de l'estuaire et du golfe du Saint-Laurent incluant également certains protozoaires. Publ Spéc Can Sci Halieut Aquat 128:1-387

Bessière A, Nozais C, Brugel S, Demers S, Desrosiers G (2007) Metazoan meiofauna dynamics and pelagic-benthic coupling in the Southeastern Beaufort Sea, Arctic Ocean. Polar Biol 30:1123-1135

Borstadt GA, Gower FJR (1984) Phytoplankton chlorophyll distribution in the eastern Canadian Arctic. Arctic 37: 234-243

Carmack EC, Macdonald RW (2002) Oceanography of the Canadian shelf of the Beaufort Sea: a setting for marine life. Arctic 55(Suppl 1):29-45

$>$ Carmack E, Wassmann P (2006) Food webs and physicalbiological coupling on pan-Arctic shelves: unifying concepts and comprehensive perspectives. Prog Oceanogr 71: 446-477

Carmack EC, Macdonald RW, Jasper S (2004) Phytoplankton productivity on the Canadian Shelf of the Beaufort Sea. Mar Ecol Prog Ser 277:37-50

Clarke KR (1993) Non-parametric analyses of changes in community structure. Aust J Ecol 18:117-143

Comiso JC (2003) Warming trends in the Arctic from clear sky satellite observations. J Clim 16:3498-3510

- Comiso JC, Parkinson CL, Gersten R, Stock L (2008) Accelerated decline in the Arctic sea ice cover. Geophys Res Lett 35, L01703, doi:10.1029/2007GL031972

Cota GF, Pomeroy LR, Harrison WG, Jones EP, Peters F, Sheldon WM Jr, Weingartner TR (1996) Nutrients, primary production and microbial heterotrophy in the southeastern Chukchi Sea: arctic summer nutrient depletion and heterotrophy. Mar Ecol Prog Ser 135:247-258

Darnis G, Barber DG, Fortier L (2007) Sea ice and the onshore-offshore gradient in pre-winter zooplankton assemblages in southeastern Beaufort Sea. J Mar Syst 74: 994-1011

DOE (US Department of Energy) (1994) Handbook of methods for the analysis of the various parameters of the carbon dioxide system in sea water; version 2, Dickson AG, Goyet C (eds), ORNL/CDIAC-74. Available at: http://andrew. ucsd.edu/co2qc/handbook.html

Dower KM, Lucas MI, Phillips R, Dieckmann G, Robinson DH (1996) Phytoplankton biomass, P-I relationships and primary production in the Weddell Sea, Antarctica, during austral autumn. Polar Biol 16:41-52

Field JG, Clarke KR, Warwick RM (1982) A practical strategy for analyzing multispecies distribution patterns. Mar Ecol Prog Ser 8:37-52

Forest A, Sampei M, Makabe R, Sasaki H and others (2008) The annual cycle of particulate organic carbon export in Franklin Bay (Canadian Arctic): environmental control and food web implications. J Geophys Res 113, C03S05, doi:10.1029/2007JC004262

Garneau MÈ, Vincent WF, Alonso-Sáez L, Gratton Y, Lovejoy
C (2006) Prokaryotic community structure and heterotrophic production in a river-influenced coastal arctic ecosystem. Aquat Microb Ecol 42:27-40

> Garneau MÈ, Gosselin M, Klein B, Tremblay JÉ, Fouilland E (2007) New and regenerated production during a late summer bloom in an Arctic polynya. Mar Ecol Prog Ser 345:13-26

Gosselin M, Levasseur M, Wheeler PA, Horner RA, Booth BC (1997) New measurements of phytoplankton and ice algal production in the Arctic Ocean. Deep-Sea Res II 44: 1623-1644

Gradinger R, Bluhm B (2005) Arctic Ocean exploration 2002. Polar Biol 28:169-170

> Gradinger R, Ikävalko J (1998) Organism incorporation into newly forming Arctic sea ice in the Greenland Sea. J Plankton Res 20:871-886

Grasshoff K, Kremling K, Ehrhardt M (eds) (1999) Methods of seawater analysis, 3rd edn. Verlag Chemie, Weinheim

Hegseth EN (1997) Phytoplankton of the Barents Sea - the end of a growth season. Polar Biol 17:235-241

Heimdal BR (1983) Phytoplankton and nutrients in the waters north-west of Spitsbergen in autumn of 1979. J Plankton Res 5:901-918

Holland MM, Bitz CM, Tremblay B (2006) Future abrupt reductions in the summer Arctic sea ice. Geophys Res Lett 33, L23503, doi:10.1029/2006GL028024

- Holmes RM, McClelland JW, Peterson BJ, Shiklomanov IA and others (2002) A circumpolar perspective on fluvial sediment flux to the Arctic Ocean. Global Biogeochem Cycles 16, 1098, doi:10.1029/2001GB001849

Hsiao SIC, Foy MG, Kittle DW (1977) Standing stocks, community structure, species composition, distribution, and primary production of natural populations of phytoplankton in the southern Beaufort Sea. Can J Bot 55:685-694

Jensen F, Hansen BW (2000) Ciliates and heterotrophic dinoflagellates in the marginal ice zone of the central Barents Sea during spring. J Mar Biol Assoc UK 80:45-54

Jensen KG, Moestrup Ø (1998) The genus Chaetoceros (Bacillariophyceae) in inner Danish coastal waters. Opera Bot 133:1-68

Johannessen OM, Bengtsson L, Miles MW, Kuzmina SI and others (2004) Arctic climate change: observed and modelled temperature and sea-ice variability. Tellus Ser A Dyn Meteorol Oceanogr 56:328-341

> Johnson KM, Wills KD, Butler DB, Johnson WK, Wong CS (1993) Coulometric total carbon dioxide analysis for marine studies: maximizing the performance of an automated gas extraction system and coulometric detector. Mar Chem 44:167-187

Knap A, Michaels A, Close A, Ducklow H, Dickson A (1996) Protocols for the Joint Global Ocean Flux Study (JGOFS) core measurements. JGOFS Report Nr. 19. Reprint of the IOC Manuals and Guides No. 29, UNESCO, Bergen

> Lee SH, Whitledge TE (2005) Primary and new production in the deep Canada Basin. Polar Biol 28:190-197

> Legendre L, Le Fèvre J (1995) Microbial food webs and the export of biogenic carbon in oceans. Aquat Microb Ecol 9:69-77

Levinsen H, Nielsen TG, Hansen BW (1999) Plankton community structure and carbon cycling on the western coast of Greenland during the stratified summer situation. II. Heterotrophic dinoflagellates and ciliates. Aquat Microb Ecol 16:217-232

> Lovejoy C, Vincent WF, Bonilla S, Roy S and others (2007) Distribution, phylogeny, and growth of cold-adapted picoprasinophytes in Arctic seas. J Phycol 43:78-89

Macdonald RW, Sakshaug E, Stein R (2004) The Arctic Ocean: 
modern status and recent climate change. In: Stein $\mathrm{R}$, Macdonald RW (eds) The organic carbon cycle in the Arctic Ocean. Springer-Verlag, Berlin, p 6-20

McLaughlin FA, Carmack EC, Macdonald RW (1996) Physical and geochemical properties across the Atlantic/Pacific water mass front in the southern Canadian Basin. J Geophys Res 101(C1):1183-1197

Mingelbier M, Klein B, Claereboudt MR, Legendre L (1994) Measurement of daily primary production using $24 \mathrm{~h}$ incubations with the ${ }^{14} \mathrm{C}$ method: a caveat. Mar Ecol Prog Ser 113:301-309

Myers JL, Well AD (2003) Research design and statistical analysis. Lawrence Erlbaum Associates, London

Not F, Massana R, Latasa M, Marie D and others (2005) Late summer community composition and abundance of photosynthetic picoeukaryotes in Norwegian and Barents Seas. Limnol Oceanogr 50:1677-1686

Olli K (1999) Diel vertical migration of phytoplankton and heterotrophic flagellates in the Gulf of Riga. J Mar Syst 23: 145-163

Parsons TR, Maita Y, Lalli CM (1984) A manual of chemical and biological methods for seawater analysis. Pergamon Press, Toronto

Parsons TR, Webb DG, Rokeby BE, Lawrence M, Hopky GE, Chiperzak DB (1989) Autotrophic and heterotrophic production in the Mackenzie River/Beaufort Sea estuary. Polar Biol 9:261-266

Peterson BJ, Holmes RM, McClelland JW, Vörösmarty CJ and others (2002) Increasing river discharge to the Arctic Ocean. Science 298:2171-2173

Pickart RS (2004) Shelfbreak circulation in the Alaskan Beaufort Sea: mean structure and variability. J Geophys Res 109, C04024, doi:10.1029/2003JC001912

Retamal L, Bonilla S, Vincent WF (2008) Optical gradients and phytoplankton production in the Mackenzie River and the coastal Beaufort Sea. Polar Biol 31:363-379

Richardson K, Markager S, Buch E, Lassen MF, Kristensen AS (2005) Seasonal distribution of primary production, phytoplankton biomass and size distribution in the Greenland Sea. Deep-Sea Res I 52:979-999

Sakshaug E (2004) Primary and secondary production in the Arctic seas. In: Stein R, Macdonald RW (eds) The organic carbon cycle in the Arctic Ocean. Springer-Verlag, Berlin, p $57-81$

Sakshaug E, Slagstad D (1991) Light and productivity of phytoplankton in polar marine ecosystems: a physiological view. Polar Res 10:69-85

Schloss IR, Nozais C, Mas S, van Hardenberg B and others

Editorial responsibility: Catherine Richardson,

Copenhagen, Denmark
(2008) Picophytoplankton and nanophytoplankton abundance and distribution in the southeastern Beaufort Sea (Mackenzie Shelf and Amundsen Gulf) during fall 2002. J Mar Syst 74:978 - 993

- Serreze MC, Holland MM, Stroeve J (2007) Perspectives on the Arctic's shrinking sea-ice cover. Science 315: 1533-1536

Simpson KG (2008) Nutrient dynamics and nitrogen-based production in the Western Canadian Arctic Ocean. MS thesis, McGill University, Montréal

> Simpson KG, Tremblay JÉ, Gratton Y, Price NM (2008) An annual study of inorganic nitrogen and phosphorus, and silicic acid distribution in the southeastern Beaufort Sea. J Geophys Res 113, C07016, doi:10.1029/2007JC004462

Slagstad D, Støle-Hansen K (1991) Dynamics of plankton growth in the Barents Sea: model studies. Polar Res 10: 173-186

Smith WO Jr, Marra J, Hiscock MR, Barber RT (2000) The seasonal cycle of phytoplankton biomass and primary productivity in the Ross Sea, Antarctica. Deep-Sea Res II 47 : 3119-3140

Sorokin YI, Sorokin PY (1996) Plankton and primary production in the Lena estuary and in the south-eastern Laptev Sea. Estuar Coast Shelf Sci 43:399-418

Thomson RE, Fine IV (2003) Estimating mixed layer depth from oceanic profile data. J Atmos Ocean Technol 20: $319-329$

Throndsen J, Hasle GR, Tangen K (2003) Norsk Kystplanktonflora. Almater Forlag AS, Oslo

Tomas CR (1997) Identifying marine phytoplankton. Academic Press, San Diego, CA

Tremblay JÉ, Klein B, Legendre L, Rivkin RB, Therriault JC (1997) Estimation of $f$-ratios in ocean based on phytoplankton size structure. Limnol Oceanogr 42:595-601

Tuschling $K$, von Juterzenka K, Okolodkov YB, Anoshkin A (2000) Composition and distribution of the pelagic and sympagic algal assemblages in the Laptev Sea during autumnal freeze-up. J Plankton Res 22:843-864

Wassmann P (2004) Particulate organic carbon flux to the seafloor of the Arctic Ocean: quantity, seasonality and processes. In: Stein R, Macdonald RW (eds) The organic carbon cycle in the Arctic Ocean. Springer-Verlag, Berlin, p 131-138

Wheeler PA, Gosselin M, Sherr E, Thibault D, Kirchman DL, Benner R, Whitledge TE (1996) Arctic cycling of organic carbon in the central Arctic Ocean. Nature 380:697-699

Zar JH (1999) Biostatistical analysis. Prentice-Hall, Upper Saddle River, NJ

Submitted: April 28, 2008; Accepted: November 2, 2008 Proofs received from author(s): February 10, 2009 